\title{
Tanduk Alit
}

\author{
Rubrik suplemen yang berisi ringkasan laporan dan output hasil \\ kegiatan pengabdian kepada masyarakat.
}

\section{Pengembangan Pengabdian kepada Masyarakat di Masa Pandemi, Bidang Sosial-Humaniora}

Pada hari Jumat, 11 September 2020, pukul 09.00-11.00 WIB, Unit Pengabdian kepada Masyarakat dan Alumni FIB UGM menyelenggarakan seminar "Pengembangan Pengabdian kepada Masyarakat di Masa Pandemi, Bidang Sosial-Humaniora" secara daring via Google Meet. Pemantik diskusi yang diundang dalam seminar ini adalah: Prof. Ir. Irfan Dwidya Prijambada Ph.D. (Direktorat Pengabdian kepada Masyarakat UGM), Dr. Hempri Suyatna, S.Sos, M.Si. (Fakultas Ilmu Sosial dan Politik UGM), Rahmawan Jatmiko, M.A. (Fakultas Ilmu Budaya, Universitas Gadjah Mada), dan Dr. Anggraeni, M.A. (Fakultas Ilmu Budaya, Universitas Gadjah Mada).

Kegiatan seminar dibuka dengan sambutan Wakil Dekan Bidang Alumni, Penelitian, dan Pengabdian kepada Masyarakat FIB UGM, Dr. Agus Suwignyo dan dilanjutkan dengan sambutan dari Dekan Fakultas Ilmu Budaya, Dr. Wening Udasmoro, M.Hum, DEA., yang sekaligus membuka kegiatan seminar. Dalam sambutannya Dr. Wening Udasmoro menyampaikan bahwa dalam pemikiran kampus merdeka perlu ditekankan mengenai kontribusi perguruan tinggi kepada masyarakat. Dalam kerangka tersebutlah pengabdian kepada masyarakat itu akan menjadi poin yang sangat penting, yaitu sebagai pengembangan keilmuan, kontribusi perguruan tinggi kepada masyarakat, dan pengembangan karir dosen. Satu hal yang menarik, Covid-19 ini memberikan satu pelajaran, yaitu bagaimana ketika ilmu kedokteran dan ilmu farmasi selama berbulanbulan itu belum berhasil mengalahkan virus ini dan ternyata salah satu aspek yang dapat mengerem penularan adalah dari aspek budaya. Itu pun belum berhasil sepenuhnya, karena membuat orang berbudaya cuci tangan, memakai masker bukan lah sesuatu yg mudah. Hal yang penting adalah melakukan sesuatu dari yang kecil tapi mungkin bisa memberikan dampak yang besar bagi masyarakat sekitar. Di akhir sambutannya, beliau mengharapkan seminar ini akan menghasilkan masukan-masukan yang sangat berguna bagi kita dalam menghadapi masa pandemi.

\section{Presentasi}

Seminar dipandu oleh Saeful Anwar, Sekretaris Unit Pengabdian Masyarakat dan Alumni di Fakultas Ilmu Budaya UGM. Pemantik diskusi yang pertama kali tampil adalah adalah Rahmawan Jatmiko, MA. dari Fakultas Ilmu Budaya. Dalam presentasinya Rahmawan Jatmiko menguraikan Program pengabdian kepada masyarakat $(\mathrm{PkM})$ yang dilakukan di Ngentakrejo, Rongkop, Gunung Kidul yang dilaksanakan melalui pendampingan Karang Taruna Tunas Harapan Ngentakrejo. Pemberdayaan masyarakat dilakukan melalui kelompok Karang Taruna. Pemilihan kelompok Karanga Taruna adalah karena Karang Taruna dapat berfungsi sebagai penghubung dari kampus sebagai pelaksana 
Tridharma PT melalui kegiatan pengabdian kepada masyarakat, dengan masyarakat khususnya masyarakat pedesaan. Di samping itu, mereka merupakan kelompok yang paling siap untuk melaksanakan kegiatan via daring. Mereka memiliki ketertarikan yang cukup besar untuk berinteraksi dengan pihak kampus. Terlebih lagi, mereka sebagai sebuah organisasi yang cukup rapi telah mempunyai program kerja. Berdasarkan observasi awal diketahui bahwa mereka pernah mendapatkan pelatihan fotografi dan videografi. Kegiatan $\mathrm{PkM}$ berfokus pada pendampingan atau pemberdayaan yang terkait dengan butir ketujuh dari visi dan misi yang telah mereka susun, yaitu "Pemupukan kreatifitas generasi muda untuk dapat mengembangkan tanggung jawab sosial yang bersifat rekreatif, kreatif, edukatif, ekonomis dan produktif”. Oleh karena $\mathrm{PkM}$ ini diselenggarakan dalam masa pandemi Covid-19 maka kegiatan PkM dilakukan secara daring.

Observasi awal yang telah dilakukan oleh tim $\mathrm{PkM}$ menemukan bahwa kegiatankegiatan Karang Taruna pun terkena dampak pandemi. Dalam bidang sosial-budaya terlihat bahwa banyak kelompok-kelompok kesenian menjadi tidak aktif dan kemudian terjadi penurunan kemampuan keterampilan dalam bidang seni. Oleh sebab itu, kegiatan PkM diarahkan pada pemberdayaan kegiatan seni-budaya melalui media video kolaboratif secara daring. Kendala yang dihadapi tentunya berkaitan dengan lemahnya atau kurang lancarnya jaringan internet yang digunakan. Dalam produksi video kolaboratif juga diselenggarakan lomba antar kelompok untuk memproduksi video kolaboratif yang terbaik.

Berdasarkan pengalaman kegiatan PkM tersebut, Rahmawan Jatmiko menyimpulkan bahwa bekal data hasil asesmen awal sangat penting untuk menyusun program $\mathrm{PkM}$ agar dapat disesuaikan dengan kelompok sasaran dan potensi apa yang telah dimiliki oleh kelompok sasaran dengan kemampuan yang dimiliki oleh tim PkM sendiri. Di samping itu, kegiatan tambahan yang menarik seperti lomba antar kelompok ikut membuat kelompok sasaran menjadi lebih antusias dalam berkegiatan. Pada dasarnya tujuan dari kegiatan PkM adalah mendampingi kegiatan Karang Taruna agar tetap produktif dan sampai menjelang berakhirnya program tersebut, di akhir bulan September, terlihat bahwa program $\mathrm{PkM}$ ini berhasil menggapai tujuan tersebut, bahkan masyarakat sasaran sudah menanyakan apakah akan dilakukan lagi kegiatan semacam dalam bidang yang lain seperti dalam bidang peningkatan ekonomi masyarakat".

Pemantik diskusi kedua dalam seminar ini adalah Prof. Ir. Irfan Dwidya Prijambada Ph.D. dari Direktorat Pengabdian kepada Masyarakat UGM. Dalam presentasinya beliau mengawali dengan cerita bahwa setelah tanggal 14 Maret 2020 pemerintah mengumumkan COVID menjadi bencana nasional alam, masyarakat menanggapinya dengan dua reaksi yang berbeda. Reaksi yang pertama, dalam istilah orang dibilang cuek bebek, seperti tidak terjadi apa-apa, semuanya berjalan seperti biasa. Tapi pada sisi yang lain, masyarakat me-lockdown kampungnya. Semua pintu menuju masuk ke kampung ditutup semua. Nah akibatnya ini, selain lockdown ini kemudian orang masuk kampung diperiksa. Kemudian masker hilang dari pasaran, hand sanitizer habis dari pasaran, Sementara di dalam kampung yang di lockdown tadi, orang luar gak boleh masuk, orang dalam boleh keluar.

Melihat kondisi saat seperti di atas, menurut Pof. Irfan diperlukan upaya meningkatkan kesadaran dengan memberikan pengetahuan yang benar tentang 
Coronavirus beserta dengan pencegahannya dan penanganan pasien yang tertular. Informasi pengetahuan tentang coronavirus disampaikan dalam bahasa yang lebih mudah dipahami oleh masyarakat. Awalnya cara yang dilakukan adalah dengan memasang Baliho, namun ternyata tidak terlalu efektif, sehingga kemudian dilakukan juga dengan metode penerangan keliling. Tentu saja dengan pendekatan yang mengena dan diterima oleh masyarakat, misalnya dalam menjelaskan pentingnya memakai masker digunakan kalimat imbauan "Saya bukan takut ketularan panjenengan tapi saya takut nulari panjenengan". Dalam kasus penyemprotan disinfektan pun penyampaiannya digunakan pendekatan yang lebih melihat kondisi sosial budaya masyarakat. Program Direktorat PkM UGM yang lain adalah pembuatan buku saku yang dilakukan bersama satgas COVID, serta melibatkan kelompok KKN UGM. Buku saku ini pun kemudian diterjemahkan dalam 10 bahasa daerah, mulai dari bahasa di Aceh sampai di Papua yang bertujuan agar informasi yang disampaikan dalam bahasa daerah dapat lebih dimengerti oleh masyarakat. Di samping itu, juga melakukan pembagian hand sanitizer ke pasar-pasar dan memberikan penjelasan tentang pentingnya jaga jarak. Berkaitan dengan hal di atas dan kenyataan bahwa PSBB masih diberlakukan, perlu sumbangan pemikiran dari Fakultas Ilmu Budaya dalam menyusun strategi komunikasi yang efektif dalam melakukan penyampaian informasi kepada masyarakat.

Prof. Irfan juga menceritakan pengalamannya dalam menanggapi permintaan kebutuhan APD dari rumah sakit dan Puskesmas melalui cara menggandeng UMKM dalam pembuatan APD. Untuk menyelamatkan UMKM yang ada dan adanya peningkatan kebutuhan APD, maka beberapa UMKM disarankan untuk berganti usaha dari usaha fashion ke usaha pembuatan APD. Dalam hal ini, bukan bantuan teknis yang diperlukan tetapi justru ide-ide baru yang dapat ditularkan ke masyarakat untuk bergerak menghadapi dan mengatasi dampak ekonomis yang sudah mulai terlihat. Selain ide peralihan bidang usaha UMKM, juga digulirkan ide-ide baru dalam pemasaran komoditas perdagangan. Pelaksanaan pemasaran yang diperkenalkan adalah pemasaran melalui media sosial online, terutama awalnya melalui aplikasi WA (Whatsapp). Aplikasi ini sangat pas digunakan karena lebih dekat dengan budaya komunikasi masyarakat, yang di dalamnya masih dimungkinkan untuk saling menyapa antara penjual dengan pembeli, yang kemungkinan besar sulit dilakukan apabila langsung bermain di marketplace besar seperti Bukalapak, Shopee atau Tokopedia. Pendampingan terhadap UMKM tidak berhenti hanya pada cara pemasaran saja, tetapi juga sampai pada pembuatan kemasan yang baik. Dalam kasus pengemasan yang baik, memang saat ini perlu banyak pembinaan untuk merubah budaya pengemasan yang lama yang biasanya seadanya menjadi bentuk yang lebih komunikatif dan menarik.

Sesi berbagi pengalaman oleh Prof. Irfan diakhiri dengan sekali lagi beliau menegaskan bahwa pendekatan budaya sungguh sangat penting dalam pendampingan masyarakat pada masa pandemi ini, bukan hanya bantuan teknis saja. Beliau berharap dapat dukungan dari teman-teman dari sosio humaiora karena masalahnya adalah perubahan budaya bukan teknis.

Pada sesi presentasi yang ketiga, tampil Dr. Hempri Suyatna, S.Sos, M.Si. dari Fakultas Ilmu Sosial dan Politik UGM. Beliau menyampaikan pengalaman pelaksanaan kegiatan pengabdian kepada masyarakat $(\mathrm{PkM})$ di Fakultas Ilmu Sosial dan Politik Universitas Gadjah Mada terkait dengan respon Fisipol dalam konteks masa pandemi 
COVID19 ini. Fisipol sebenarnya sejak awal pandemi sudah meluncurkan hibah PkM. Lebih jauh menurutnya, banyak isu-isu menarik terkait tantangan dan konteksnya di masa pamdemi ini yang dapat dilakukan bagi pelaksanaan $\mathrm{PkM}$, seperti isu kesehatan, keselamatan, dan respon masyarakat sasaran. Jadi kalau bicara tentang konteks pengabdian di era pandemi sebenarnya ada banyak hal yang dapat dilakukan oleh bidang sosial humaniora. Pemberitaan yang hoax misalnya, Fakultas Ilmu Budaya punya kepedulian dan keterkaitan di isu ini, terkait dengan keilmuan FIB. Di samping itu, isu kemiskinan, pengangguran, pembelajaran, pendidikan, wisata, juga menarik untuk kegiatan PKM.

Dalam literatur-literatur yang terkait antara pandemi dan internet terlihat internet menjadi penyelamat UKM dari krisis COVID-19. Hal ini menjadi dasar bagi Fisipol untuk mengembangkan model pemberdayaan dengan aplikasi model belanja online, yang diterapkan di Pasar Sambilegi, Maguwoharjo, Kabupaten Sleman. Data yang ada menunjukan bahwa 59\% sektor UMKM sekarang sudah beralih mekanisme penjualannya ke mekanisme via internet, melalui apa yang dikenal dengan belanja online. Pekerjaan rumah yang muncul adalah bagaimana kemudian literasi digital, melek digital bagi masyarakat itu menjadi sangat penting.

Kegiatan PkM Fisipol yang pertama adalah pelatihan dan pendampingan model belanja online di Pasar Sambilegi, Sleman, mengembangkan model belanja online dengan membuat aplikasi model belanja online. Pasarsambilegi.id adalah adalah karya Fisipol yang bekerja sama dengan Pusat Studi Ekonomi Kerakyatan di UGM. Kegiatan PkM yang kedua adalah mengembangkan konsep urban farming yang ada di wilayah di Kampung Badran. Kegiatan ini memang tidak sepenuhnya 100\% daring, paling tidak 10-20\% dilakukan secara luring karena ada beberapa hal esensial yang memang tidak bisa dilakukan secara daring, misalnya ketika acara kulonuwun di awal kegiatan. Oleh karena masyarakat sasaran adalah kelas menengah ke bawah menyebabkan dilakukannya satu kali sosialisasi untuk bertemu dan interaksi dengan masyarakat yang tentunya dengan protokol kesehatan. Delapan puluh persen kegiatan dilakukan daring, misalnya pelaksanaan aplikasi model, pamflet-pamflet terkait dengan promosi-promosi Pasar Sambilegi, dan beberapa kegiatan daring lainnya. Terkait dengan model belanja online, terdapat dua hal yang menjadi pertimbangan pembuatan model belanja online. Pertama, resiko sumber penyebaran virus Covid-19 meningkat di antara para pedagang di berbagai daerah kabupaten dan provinsi. Kedua, sebagian besar pedagang belum memahami pencegahan terkait dengan Covid-19 dan untuk berbelanja langsung ke pasar masyarakat menjadi ketakutan dan khawatir tertular. Tim PkM kemudian mengembangkan branding eksistensi pasar dengan mengembangkan pasarsambilegi.id. Diharapkan dengan solusi ini masyarakat dapat berbelanja dengan aman dan nyaman. Alasan dipilihnya pasar Sambilegi sebagai sasaran kegiatan PkM karena secara historis Fisipol atau mungkin juga Pusat Studi Ekonomi Kerakyatan itu sudah lama berkiprah di pasar Sambilegi, antara lain dahulu pernah mengelola Sekolah Pasar Rakyat di Pasar Sambilegi.

Pasarsambilegi.id menggunakan platform website agar sangat mudah digunakan dan tidak akan menambah aplikasi telepon genggam. Paguyuban pasar Sambilegi bersama Fisipol UGM dan Pustek ingin mengembangkan tidak hanya model belanja online semata tetapi mengembangkan model belanja online yang berbasis pemberdayaan komunitas. Fungsi Tim PkM Fisipol lebih ke monitoring dan evaluasi atas model belanja yang sedang berjalan. Penekan pendampingan masyarakat ini ada pada pemberdayaan 
komunitas yang ada di pasar Sambilegi dan respon komunitas juga luar biasa. Ke depan akan direncanakan kerjasama Disperidag Kabupaten Sleman ini. Aplikasi ini secara perlahan-lahan nanti akan diserahkan ke Dinas Perindustrian Perdagangan Sleman untuk nanti pengelolaan ke depan akan dikelola oleh Dinas Perindag Sleman. Akhir tahun ini mungkin akan diserahkan tapi sekarang masih dilakukan proses pendampingan di Pasar Sambilegi dan memang tantangannya adalah mendorong literasi digital untuk masyarakat.

Saat ini sedang dilakukan replikasi kegiatan di Pasar Kolombo. Kali ini bekerja sama dengan pemerintah desa di Condongcatur, Kabupaten Sleman untuk mengembangkan model belanja online di Pasar Kolombo dengan lebih komprehensif. Harapanya dua bulan ke depan ini sudah bisa launching, dan mungkin akan lebih lengkap rinci terkait dengan model pendanaan yang ada, yang memang dialokasikan untuk memodernisasi pasar-pasar yang ada di wilayah Condongcatur.

Program PkM yang kedua adalah program pengembangan pertanian dengan sistem aquaponik dengan sasaran utamanya adalah korban PHK dan mereka yang terkena dampak pandemi Covid-19 karena banyak sektor-sektor informal yang harus gulung tikar. Program ini dilaksanakan di kampung Badran, Yogyakarta. Masyarakat Badran sendiri memiliki potensi untuk mengembangkan pertanian di daerah perkotaan. Model pembelajaran yang diterapkan beragam, beberapa melalui video atau leaflet dan sesekali ke lapangan.

Sebagai kesimpulan, Dr. Hempri mengemukakan bahwa sebenarnya ada banyak hal yang dapat ditawarkan di era pandemi ini oleh teman-teman sosial humaniora. Isu literasi dan isu model pembelajaran digital akan menjadi isu yang dapat lebih dikuatkan. Hal lain yang terkait dengan pengembangan digital adalah menampilkan budaya secara virtual yang mungkin menarik untuk dikerjakan. Beberapa destinasi wisata sudah mengembangkan konsep-konsep kunjungan wisata di era adaptasi kebiasaan baru. Kemudian juga pengembangan e-commerce web platform misalnya, atau wisata virtual yang banyak juga dilakukan oleh teman-teman pariwisata. Prodi Pariwisata memiliki potensi untuk mendorong wisata-wisata virtual, wisata-wisata dari sisi historis maupun wisata yang memungkinkan atraksi alam dan sebagainya. Di samping itu, Dr. Hempri mengatakan bahwa konsep-konsep pengembangan kampungpreneur berbasis digital smart village dan sebagainya dapat lebih dikembangkan. Kemudian advokasi-advokasi kebijakan pemerintah dalam bentuk policy brief, policy paper dapat dilakukan karena banyak kebijakan-kebijakan yang mungkin tidak pas dan tidak tepat.

Pemantik diskusi terakhir adalah Dr. Anggraeni M.A. yang menyampaikan pengalamannya melaksanakan PkM di Gunung Wingko, Bantul. Dr. Anggraeni membeberkan pengalaman pribadinya dalam pelaksanaan $\mathrm{PkM}$ yang sangat spesifik yang terkait dengan bidang ilmu yang ditekuni. Tiga hal yang dikemukakannya, yaitu kegiatan PKM di bidang arkeologi yang selama ini yang sifatnya konvensional yang sudah dilakukan; kemudian evaluasi dan perubahan bentuk PkM yang ada sebelum masa pandemi; dan terakhir adalah modifikasi yang dilakukan pada masa pandemi.

Bentuk $\mathrm{PkM}$ konvensional biasanya dilakukan dalam bentuk sosialisasi tatap muka dengan jumlah peserta yang banyak dan satu arah sifatnya. Di arkeologi biasanya dilakukan untuk memberikan sosialisasi tentang temuan-temuan arkeologi di suatu situs. Kemudian juga kadang-kadang dilakukan bersamaan dengan kegiatan penelitian. Ini 
semua sifatnya satu arah, yang diharapkan masyarakat dapat mengetahui keberadaan tinggalan-tinggalan arkeologi dan dapat memelihara tinggalan tersebut. Kemudian ada evaluasi dan perubahan bentuk dan konsep kegiatan PKM, masyarakat setempat mulai dilibatkan dalam pelestarian yang berbasis potensi setempat. Awalnya dimulai dengan melihat potensi masyarakat di sekitar situs arkeologi terlebih dahulu sebelum melakukan kegiatan PkM. Salah satu yang pernah di dilakukan arkeologi adalah kegiatan PkM di masyarakat Sojiwan. Di sekitar Candi Sojiwan terdapat kelompok pembatik dan kelompok penghasil kuliner yang khas. Kegiatan ini dilakukan sebelum pandemi, pembatik yang ada di sekitar lokasi situs itu diajak untuk memanfaatkan relief candi untuk mengembangkan motif batik. Kemudian dilaksanakan pelatihan-pelatihan untuk menghasilkan motif batik khas Sojiwan. Pelatihan itu terus dilakukan mengingat kadang-kadang orang hanya secara mentah mengalihkan motif hias pada candi untuk diterapkan pada batik, sehingga motifnya kurang menarik. Pelatihan diselenggarakan untuk membuat motif batik berbasis motif relief menjadi lebih indah.

Kasus yang oleh Dr. Anggraeni angkat dalam kegiatan program PkM-nya adalah situs Gunung Wingko yang sebenarnya merupakan situs yang jarang sekali diketahui oleh masyarakat luas, bahkan oleh masyarakat di sekitar wilayah situs itu sendiri yaitu di Kecamatan Sanden. Pelaksanaan PkM di wilayah situs tersebut sudah berjalan dua tahun yang melibatkan mahasiswa untuk menjajaki pengetahuan masyarakat tentang keberadaan situs. Tim PkM juga terlibat dalam pameran tahunan Sanden Fair. Justru dari keikutsertaan di Sanden Fair itu kemudian diperoleh banyak informasi tentang potensi yang dimiliki oleh masyarakat sekitar seperti kegiatan membatik, potensi agro dan kuliner. Terkait dengan potensi-potensi yang dimiliki masyarakat sekitar situs Gunung Wingko, kemudian dikembangkan kegiatan $\mathrm{PkM}$ yang bertujuan untuk menyiapkan embrio Pusat Informasi Gunung Wingko agar Gunung Wingko, yang terletak sangat dekat dengan objek wisata Samas itu dapat dikenal pula oleh masyarakat luas. Walaupun penampilan situs Gunung Wingko sendiri bukan merupakan tinggalan monumental, tetapi merupakan bukit pasir atau gumuk pasir yang mengandung ribuan fragmen gerabah kuno yang sebenarnya tidak dipahami keberadaannya oleh masyarakat sendiri. Untuk dapat mengangkat situs Gunung Wingko ini menjadi destinasi wisata minat khusus agar masyarakat tahu bahwa di sana pada masa lalu pernah ada pemukiman dari masa 1500 tahun tahun lalu, perlu dikaitkan dengan potensi wisata yang ada di daerah itu.

Permasalahannya adalah bagaimana dapat melestrikan situs tersebut dari dampak kegiatan permukiman pada masa sekarang, bahwa sebenarnya bukit pasir tersebut saat ini banyak yang sudah ditambang oleh masyarakat. Penambangannya sangat intensif, yang semula tingginya sekitar 10 meter kemudian sudah digali sekitar 3 sampai 5 meter, sehingga menyebabkan gumuk pasir yang ada atau beting gisik yang ada di sana menjadi hilang. Padahal gumuk pasir merupakan fenomena alam yang khas yang tidak terjadi pada semua pantai di pesisir selatan Jawa. Selain itu, bukit pasir yang masih mengandung tinggalan arkeologis menjadi tidak jelas penampakannya karena bercampur dengan aktifitas masyarakat sekarang. Bahkan, ada juga kegiatan menggali lubang kubur di bukit pasir tersebut, yang kemudian menampakkan sisa-sisa fragmen gerabah yang ada di situs tersebut.

Upaya pelestarian diwujudkan melalui kegiatan PkM adalah dengan sosialisasi 
dua arah, FGD, dan pameran. Pada tahun ini direncanakan akan dilakukan PkM tahap ketiga berupa implementasi pendirian Pusat Informasi Gunung Wingko, namun tidak dapat dilaksanakan terkait dengan terjadinya pandemi Covid-19, sehingga harus dilakukan modifikasi rencana PkM tersebut. Modifikasi dilakukan dengan mengubah menjadi pelaksanaan pembuatan media visual tentang informasi situs Gunung Wingko. Harapannya adalah bukan hanya masyarakat lokal saja, yang semula itu menjadi sasaran Pusat Informasi Gunung Wingko atau orang yang datang di sekitar Samas, justru dapat diakses oleh kalangan yang lebih luas, misalnya melalui Youtube atau kanal ilmu. Wisata minat khusus ini dapat dialihkan ke dalam bentuk wisata virtual. Narasi-narasinya juga dapat diceritakan oleh masyarakat secara daring. Rencana ke depan Karang Taruna akan menjadi ujung tombak untuk melakukan pelestarian situs. Kegiatan ToT secara daring terhadap Karang Taruna itu menjadi hal yang penting. Potensi wisata virtual seperti yang dilakukan oleh prodi pariwisata menjadi hal yang dapat dilakukan. Modifikasi bentuk PkM menghadapi masa pandemi ini, misalnya yang di Candi Sojiwan, dapat dilakukan dengan mengajak pembatik itu untuk latihan pembuatan motif batik secara daring. Demikian juga dengan hasil produksi kuliner yang khas di sekitar Sojiwan, pemasarannya bisa dilakukan secara online. Mungkin dapat bekerja sama dengan situs atau link yang diciptakan oleh Pak Hempri dan teman-teman.

\section{Diskusi}

Setelah para pemantik diskusi menyampaikan pengalaman dan gagasan-gagasan dalam kegiatan PkM, kemudian dilanjutkan ke sesi diskusi. Sesi diskusi ini dipandu oleh Dr. Agus Suwignyo.

Peserta web seminar yang pertama kali mengajukan pertanyaan beserta dengan komentar adalah Prof. Faruk, beliau mengamati bahwa walaupun kita sudah berupaya dengan berbagai cara untuk mencegah penularan, namun kenyataannya pandemi masih terus berlanjut. Kita harus memikirkan ulang apa langkah-langkah yang selama ini kita tempuh sudah benar dan efektif atau tidak. Beliau mempunyai kesan bahwa kita berada di dalam suasana yang seakan-akan sangat darurat dan kita seperti panik. Ketika panik akademisi kehilangan posisi dan sifat akademisinya. Hal lain yang dipertanyakan adalah masalah keterpaduan interdisipliner dan lebih bersifat strategis dalam perencanaan penanggulangan pandemi. Di samping itu kita harus memikirkan lagi untuk membuat masukan dalam kerangka dunia akademik, dengan memanfaatkan data-data yang sudah diperoleh dari beberapa kegiatan yang dilakukan oleh UGM. Lebih lanjut, hal yang lebih penting adalah bahwa seorang akademisi melakukan kegiatan pengabdian harus berbasis pengetahuan, pengetahuan akademik yang nantinya berupa konsep yang diintegrasikan antara pengabdian, pengajaran dan penelitian.

Menanggapi komentar dan pertanyaan dari Prof. Faruk, Prof. Ir. Irfan Dwidya Prijambada Ph.D. mengamini kenyataan bahwa karena panik semua orang menjadi tergesa dan tergopoh-gopoh dalam merencanakan penanggulangan pandemi. Beliau juga setuju dengan Prof. Faruk bahwa penting untuk mengetahui apa yang terjadi di masyarakat, misalnya kebutuhan masyarakat dalam menangkas hoax yang muncul di saat pandemi dan permasalahan lockdown di kampung-kampung. Tanggapan selanjutnya dikemukakan oleh Dr. Hempri Suyatna, S.Sos, M.Si. bahwa beliau sepakat dengan Prof Faruk tentang perlunya grand design yang berbasis keilmuan dan bersifat kolaboratif. 
Dr. Hempri memberi contoh dalam konteks Pasar Sambilegi yang adalah sebuah model pemberdayaan aplikasi yang tidak sekedar membuatkan aplikasi tetapi model pemberdayaan yang berbasis komunitas. Komunitas itu lah yang nanti akan kemudian mengembangkan itu, termasuk di urban farming dan sebagainya. Selanjutnya, perlu ada level pemberdayaan di era pandemi yang mungkin lintas fakultas.

Prof. Faruk untuk kedua kalinya menggulirkan komentar tentang asumsi yang sering digunakan dalam pelaksanaan penanggulangan pandemi yang seolah-olah orang sepakat dengan kita, yang kemudian melihatnya sebagai problem teknis. Pertanyaan lebih ke arah kepada orang yang sepakat dengan kita untuk sama-sama mengatasi ini tetapi bukan bertanya kepada orang-orang yang justru menjadi sumber masalah. Masalah juga hadir ketika para aktivis yang banyak terlibat, sehingga pandangan aktivis dan pandangan teoritik itu menjadi tidak berimbang. Untuk itu perlu berkolaborasi, sehingga pendekatannya lebih dan komprehensif.

Dr. Agus Suwignyo, sebagai moderator sebelum masuk ke sesi diskusi berikutnya, menambahkan bahwa dharma pengabdian memang keberadaannya adalah secara langsung, secara operasional, atau lebih tepatnya kontekstual. Masyarakat akademik di tengah masyarakat mencoba membantu, mendampingi dan kemudian mengakselerasi penyelesaian problem-problem sosial kemasyarakatan. Jadi memang ada tarik ulur. Pengabdian adalah sesuatu yang menjadi aktifitas yang menjadi variabel penting dalam mendekonstruksi konsep menara gading universitas. Jadi universitas tidak hanya yang besar, abstrak, teorietis dan seterusnya, tapi juga yang praktis, implementatif, dan yang lintas bidang. Sesuatu yang harus menjadi tantangan terbesar adalah aspek lintas bidang yang mengharuskan untuk keluar dari klaster-klaster maupun dari kandang-kandang keilmuan kita untuk bekerja bersama. Selanjutnya beliau mengajukan pertanyaan tentang bagaimana kita memposisikan diri dalam kerja dan dalam program yang jadi tugas kita, tugas formal kita, tetapi terkoneksi secara kontekstual dengan dinamika masyarakat saat ini dan yang sedang memang menghadapi situasi pandemi yang mengharu biru.

Rahmawan Jatmiko, M.A. kemudian memberikan tanggapan terkait dengan respon yang disampaikan oleh Prof Faruk dan Prof Irfan. Beliau setuju bahwa kita semua panik dan tidak ada yang siap. Namun ada dua hal yang mungkin harus dibedakan. Dalam pandemi ini, sebagai orang dari bidang sosial humaniora, apakah sudah berpikir untuk memutus rantai pandemi dan menahan laju virusnya atau kita dapat meminimalkan dampak pandemi. Bahwa yang sudah dilakukannya bersama tim PkM lebih berfokus pada pengurangan dampak pandemi.

Selanjutnya Dr. Anggraeni menambahkan bahwa forum ini justru penting, tanpa mengesampingkan hal-hal yang mendasar seperti yang telah dikemukakan oleh Prof. Faruk, peluang untuk masukkan kolaborasi menjadi hal yang sangat mungkin untuk dilakukan. Dengan melihat secara komprehensif permasalahan yang ada, membuka peluang untuk berkolaborasi dengan pihak-pihak lain.

Web seminar yang telah berlangsung selama kurang lebih dua jam kemudian ditutup oleh Dr. Agus Suwignyo, sebagai moderator dan juga sekaligus Wakil Dekan Bidang Alumni, Penelitian, dan Pengabdian kepada Masyarakat FIB UGM, dengan menyimpulkan bahwa cukup banyak hal yang dapat dipelajari bersama dalam seminar ini. Beliau melemparkan harapan bahwa dalam penyiapan kegiatan pengabdian masyarakat dapat lebih engage dengan masyarakat sasaran dan sesuai dengan konteks persoalan saat 
ini. (Dirangkum oleh Tjahjono Prasodjo. Terimakasih kepada Fiani Ramadhania yang telah mentranskrip rekaman seminar) 